J. Perinat. Med. $11(1983) 26$

\title{
Microprocessor-based long term cardiorespirography I. Heart rate changes and apneic attacks
}

\author{
H. Hörnchen, R. Betz, V.Siller, P. Roebruck
}

Departments of Pediatrics (Director: Professor Dr. H. Schönenberg) and Medical Statistics and Documentation (Director: Professor Dr. med., Dipl. Math. R. Repges), Medical Faculty, RWTH-Aachen, West Germany

\section{Introduction}

Cardiorespirography is defined as the simultaneous recording of cardiac and respiratory action by means of a slow recorder. The cardiogram is obtained by beat to beat analysis, a proven technique of evaluating fetal heart rate changes for cardiotocography since the early 1960's $[3,9,14]$. The duration of the interval between two subsequent R-peaks is measured (interval analysis) and recorded as heart rate in beats per minute (bpm). This has been termed instantaneous heart rate. Extent and variations of cardiac action corresponding exactly to cardiac events are being recorded. This is in contrast to the averaged heart rate method where heart rates are obtained by integrating mean values over 5 to 10 seconds. This method suppresses important information. Variations in heart rate are not expressed at all or appear in smoothed or delayed form. This method is entirely satisfactory for routine cardiac monitoring; of advantage is the relatively stable signal.

Investigators headed by KLÖCK [22], EKERT [6], and STEMMANN [37, 38] respectively, established modern cardiorespirography. Instead of uterine motility (tocography) respiratory activity obtained rheographically was recorded (respirography). The deflection of the pen occurs synchronous with each breath. Apneic attacks of varying duration, periodic breathing, and other types of respirations as well as oscillations of cardiac action could be documented relatively reliably: The interpretation was exclusively by visual means.

\section{Curriculum vitae}

Dr. HELMUT HöRNCHEN attended medical school from 1963 to 1969 at the Universities of Bonn and Innsbruck. Since 1971 he has been with the Department of Pediatrics at the RWTH Aachen where he qualified as Privat Dozent in 1981. His work includes publications on respirators, parenteral nutrition and monitoring methods in neonatal intensive care.

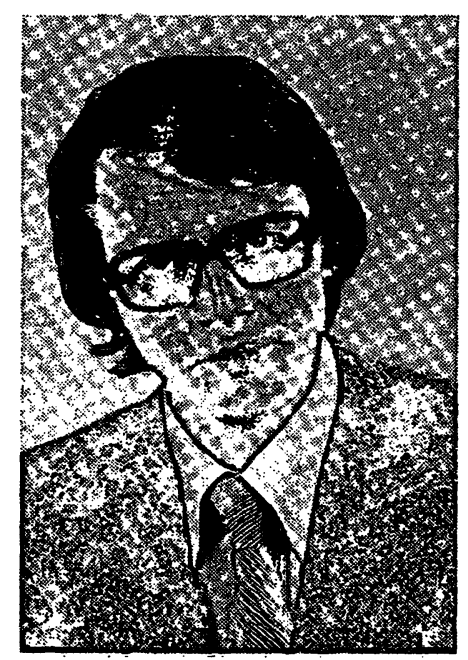

HoN et al. [15] in 1975 introduced the terms short-time variability (STV) and long-time variability (LTV) for the interpretation of cardiac action. Their interpretation was still visual. However, indications of STV and LTV by event markers eased this task somewhat $[15,16]$.

The teams of VÄLIMÄKI [40] and KERO [21] respectively, were the first to present systematic examinations of heart rates in well and sick newborns and prematures. They based their work on long-term EKG analysis and used large computers. More recently, cardiorespirography has been combined with the transcutaneous measurement of the partial pressure of oxygen as oxygen-cardiorespirography [16]. By this means the originally assumed correlation between hypoxia and lack of oscillations [22] could not be confirmed by visual 
interpretation of the recordings $[18,43]$ nor by means of computer analytic methods [8].

The current study intends to examine the value of machine computed cardiogram parameters and the reliability of automatic recognition of heart rate changes and apneic attacks in prematures and term newborn infants.

\section{Methods}

For all recordings we used a modified cardiotocographic recorder and a specially designed microprocessor-based computing unit (Fig. 1). The tocography module of the cardiotocograph was replaced by a respirography module which monitored respiration by impedance pneumography.

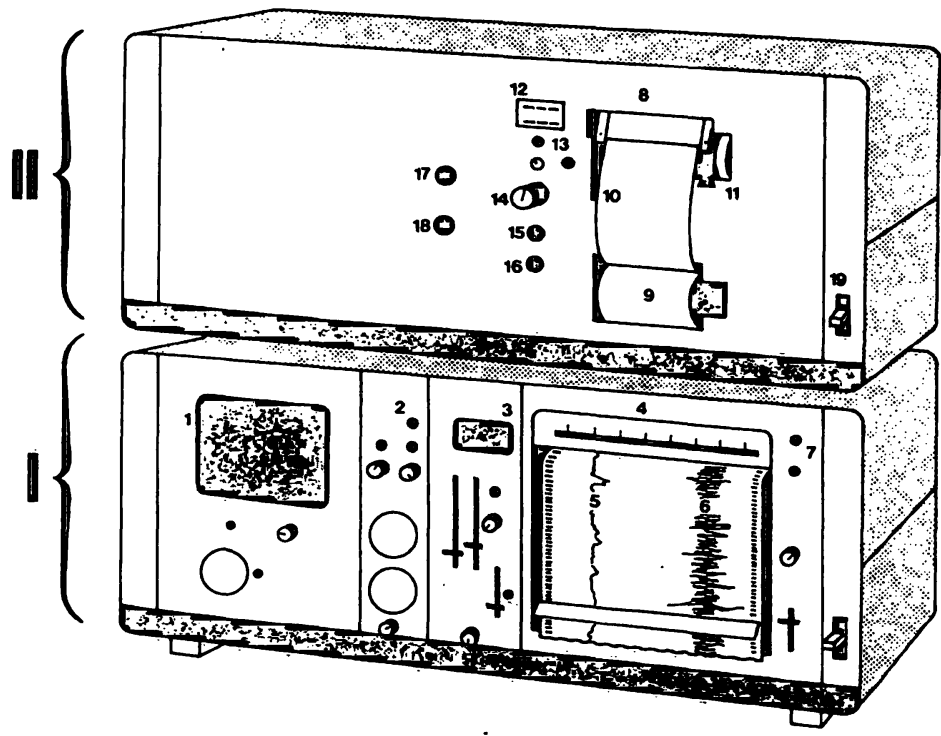

Fig. 1. Equipment Combination (prototype by SIEMENS Company, Erlangen)

I. Cardiorespirograph: 1 oscilloscope; 2 respiratory monitor module (impedance method); 3 cardiac monitor module with digital indication of averaged heart rate; 4 recorder for cardiac activity $(5$, beat to beat tracing) and respirogram (6); 7 alarms (continuous recording or recording for two minutes with alarm events).

II. Computer: 8 printer with paper supply (9); paper release (10), manual paper advance (11); 12 selector for page number at beginning of record; 13 switch for acoustical and visual alarms; 14 apnea time selector (10, 20, 30 seconds); 15 alarm reset button; 16 manual printout trigger; 17 selector for printer (printout only for alarms or printout every five minutes and for alarms); 18 event marker to reset the five minute storage grid to zero and marking of drug administration.
During a pilot program the cardiorespirograms were taperecorded. These tape recorded data served to develop a program for the computer analytical data processing. The computing unit consisted of a hardware part containing in semiconductor memories the processing algorhithms in the form of a software program and a metalpaper printer which yielded either alarm printouts only or additional routine printouts every five minutes. The printouts could be checked for accuracy with the simultaneously writing cardiorespirogram (paper speed $20 \mathrm{~mm} / \mathrm{min}$ ). We have described the signal processing elsewhere $[11,12$, 13]. Printouts and records were correlated with page numbers and automatic event markers for printouts on the cardiorespirogram record. Alarm situations causing a printout simultaneously with

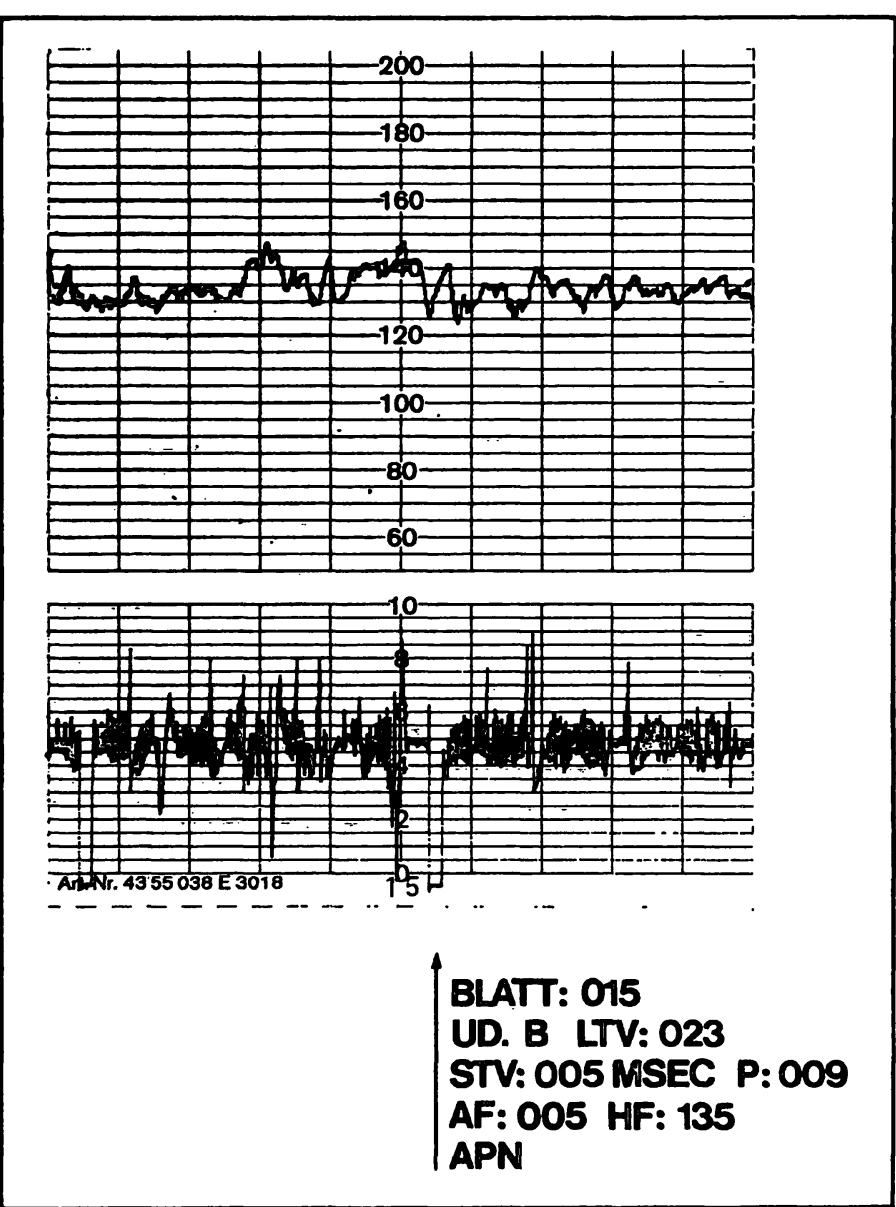

Fig. 2. Cardiorespirography recorder and printout for an apneic attack (alarm printout). Numbers and letters in the original printout have been enhanced for better reproduction; this was also done for Figs. 3, 4, and 5. 
a visual and acustic alarm signal were defined as follows:

1) Apneic attacks - The length of apnea after which an alarm and a printout is to occur is variable (10, 20 or 30 seconds). After the selected time has elapsed without respiratory activity an alarm printout will occur marked as apnea (APN; Fig. 2). Simultaneously the following information is indicated: the parameters of heart rate variability from the last "routine" printout (see part II), the instantaneous heart rate and the respiratory rate. The respiratory rate is calculated from the formula $(\alpha) A F=R_{1}-\left(R_{1}-R_{2}\right) / 8$. In this formula $A F$ is the respiratory rate on the printout, $R_{2}$ is the reciprocal value of the time interval between the two preceeding respiratory trigger impulses multiplied by 60 , and $R_{1}$ is the similarly obtained AF value. This formula results in a moderate smoothing of the values.

2) Tachycardia - (Heart rate $>180 / \mathrm{min}$; code TACHY). A tachycardia results in a printout after at least a 20 tachycardia beats. Within the 20 beats a maximum of 10 beats deviating into the normal range are permitted.

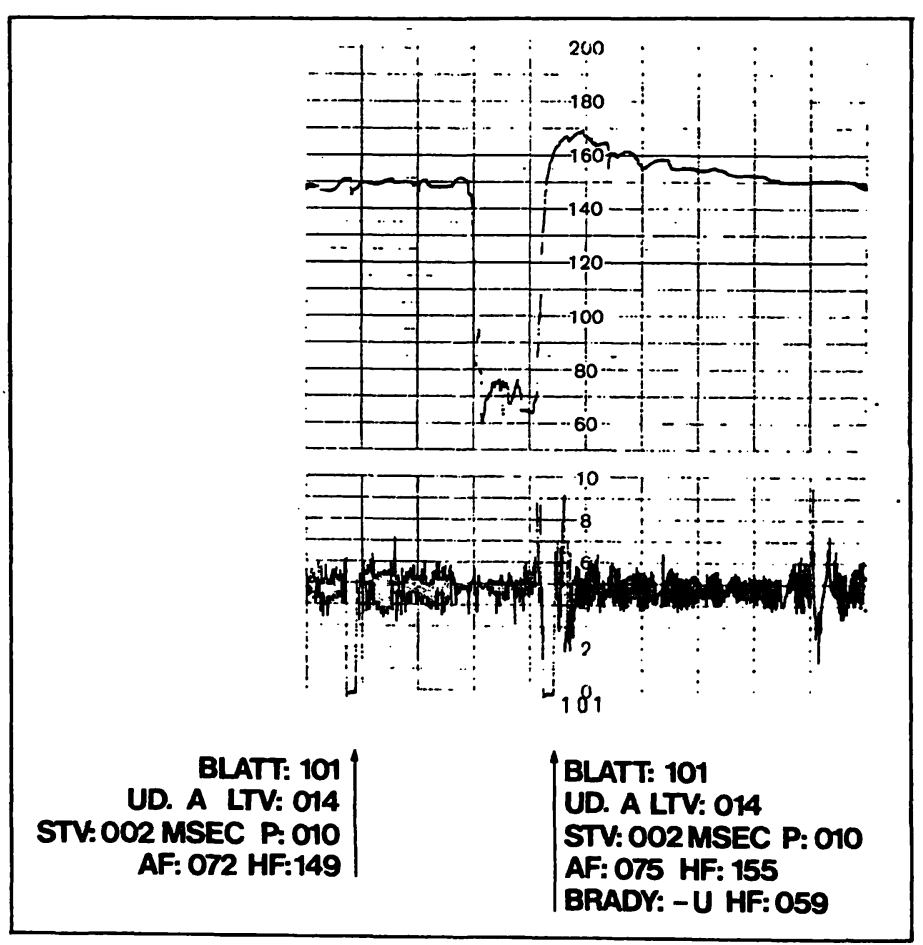

Fig. 3. V-shaped bardycardia.
3) Bradycardia - (Heart rate $<80 / \mathrm{min}$; printout code: BRADY). A printout for bradycardia occurs:

a) as "V" - bradycardia (Fig. 3) following minimally two, maximally five bradycardic beats. Behind the code for bradycardia a " $-V$ " is printed out and thus indicates that it is a V shaped decrease and increase of the heart rate. Instead of the otherwise customary indication of actual heart rate the lowest heart rate during the $\mathrm{V}$ bradycardia is documented.

b) as "U"-bradycardia after at least 10 bradycardic beats (Fig. 4). The U shaped course of bradycardia is marked by " $-U$ " and the lowest heart rate is indicated. The bradycardia printout occurs only after at least 20 normal beats have been counted following the bradycardic event.

c) if simultaneously with the bradycardia an apnea occurs before the end of the bradycardic event the code "APN + BRADY" causes an alarm printout (Fig. 5). The correlation between $\mathrm{V}$ or $\mathrm{U}$ bradycardia respectively is then obtained in a second printout following normalization of the heart rate.

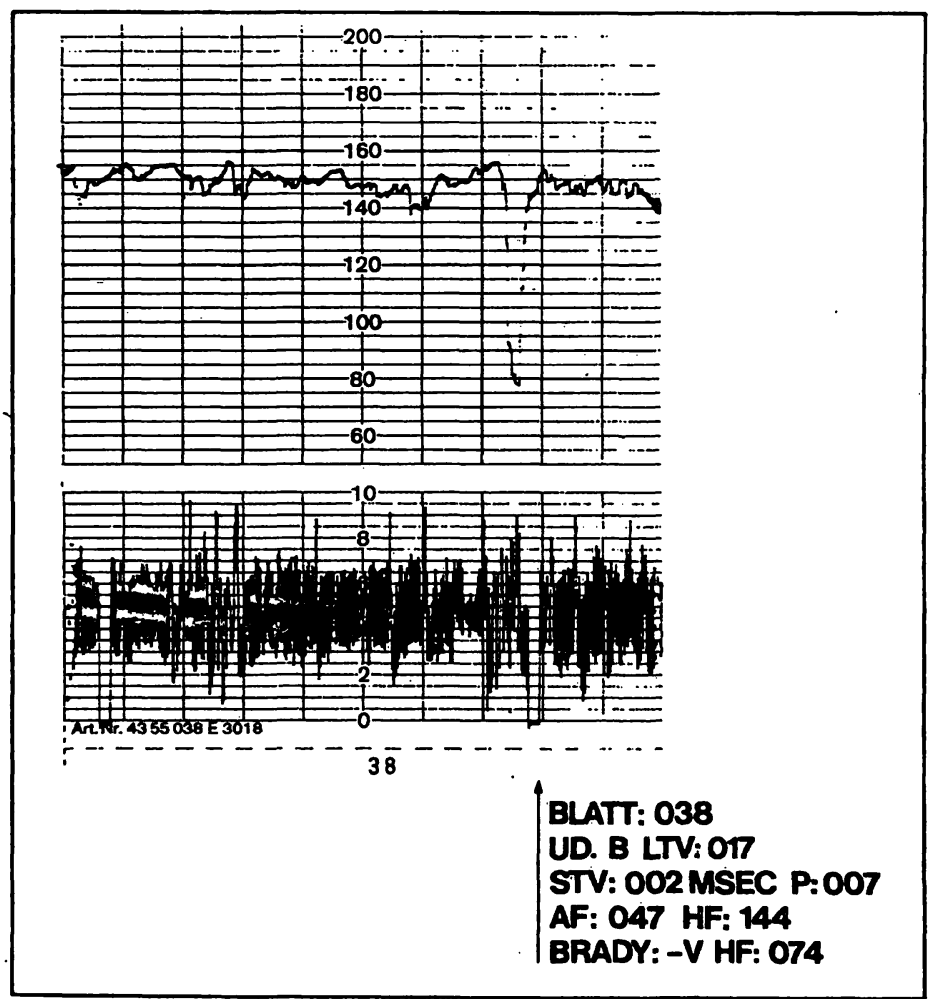

Fig. 4. U-shaped bradycardia. On the right margin there is a routine printout (see part II). 


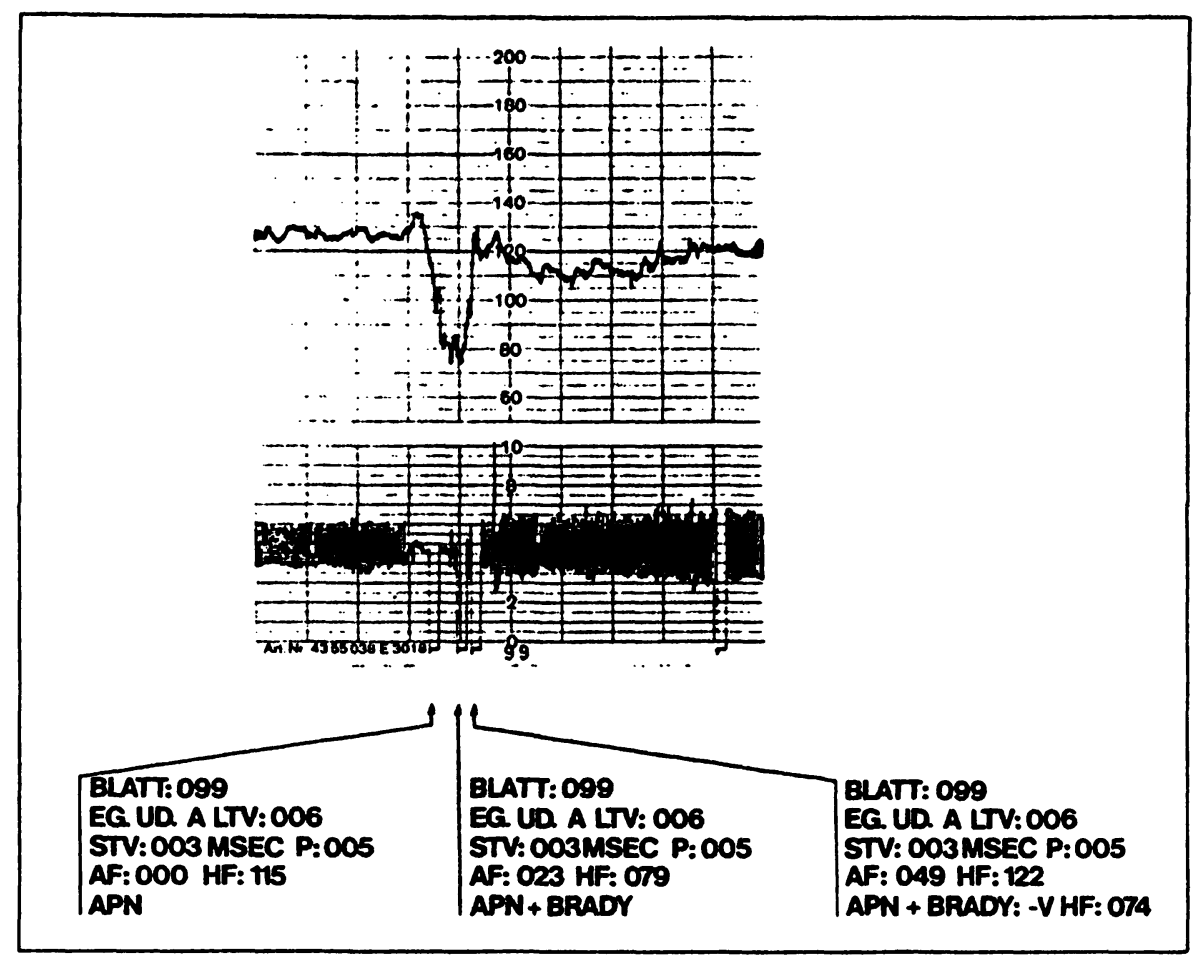

Fig. 5. Cardiorespirogram and alarm printout for an apneic attack followed by bradycardia. The type of bradycardia is indicated in a third printout.

\section{Results and discussion}

The reliability of the computing unit for recognition and classification of alarm situations was evaluated by comparing the printouts with the simultaneously recorded cardiorespirograms. A total of 5712 hour records from 41 patients were evaluated. Figs. 2 to 5 were obtained from these recordings. Six hundred alarm situations occurred and are summarized in Tab. I. For all tachycardia alarms the computer output and cardiorespirography record coincided. Nearly all bradycardia (V-shaped, U-shaped, and combination of bradycardia and apnea) were correctly recognized. With the selection of ten seconds apnea time, the computer never "overlooked" any apnea, but the number of apnea alarms without correlation in the cardiorespirography record ("false positive" alarms) was very large. With a 20 second apnea time considerably fewer "false positive" printouts were obtained. However, there were 9 unrecognized apneic attacks ("false negative").

A total of $81.5 \%$ of all alarm printouts were correct; there were $16.8 \%$ false alarms of V-bradycardias were in reality U-bradycardias. About
$2 \%$ of all alarms were not recognized by the computer.

Efficiency and accuracy of the computer output depend primarily on the reliability of the biological signals via the cardiorespirograph. The recording of the cardiac action is relatively nonproblematic. However, it is still difficult to obtain clear respiratory signals with techniques usable for prematures and newborns. Excessive spontaneous

Tab. I. Results of 600 alarm printouts.

\begin{tabular}{lrcc}
\hline & \multicolumn{3}{c}{ Alarm Printout } \\
& Correct & False & False \\
& & Positive & Negative \\
\hline Apnea, 10 seconds & 107 & 81 & - \\
Apnea, 20 seconds & 120 & 16 & 9 \\
Apnea and Bradycardia & 34 & - & - \\
V-shaped bradycardia & 110 & 1 & 1 \\
U-shaped bradycardia & 31 & $1)$ & - \\
Tachycardia & 87 & - & - \\
Total & 489 & 98 & 10 \\
\hline
\end{tabular}

1) Three U-shaped bradycardias were falsely interpreted as V-bradycardias by the computer. 
movements and nursing measures frequently lead to artifacts which are ,recognized" with the impedance method falsely as respiratory signals and prevent apnea alarms. Variations in chest excursion may trigger false positive apnea alarms. Occasionally respiratory arrests will not register because the computer mistakenly takes the impedance changes derived from cardiac action for respiratory activity [27]. The latter can largely be avoided by careful placement of the two respiratory electrodes.

In small prematures respiratory signals are generally strong and free of noise, if one electrode is placed below the xiphoid process and the second electrode opposite on the back. In term newborns it suffices to place the electrodes on the chest in the mid-axillary line at the level of the diaphgram. The quality of the respiratory signal must always be checked on an oscilloscope screen.

Microprocessor based cardiorespirography in its present form can only inform about cardiac and respiratory activity even when the variability of the heart rate is additionally considered (see part II). Any simultaneously existing hypoxia cannot be assumed in every case of heart rate changes or respiratory disturbances [44]. In apnea with bradycardia in prematures and term newborns as a rule respiratory activity stops first and the heart rate drops afterwards. The transcutaneous oxygen tension decreases even later [17, 32]. If the apnea and bradycardia alarms are observed appropriately, hypoxia may be prevented. On the other hand hypoxic events with unchanged cardiac and respiratory activity occur commonly [31].

It does not appear appropriate to rely exclusively on the computer printouts and to discontinue the recording of beat to beat cardiac heart rate and the respiratory wave form. The use of the cardiorespirogram recorder as an alarm recorder which automatically records upon the triggering of an alarm from the microcomputer is in our experience not a satisfactory solution. In order to differentiate false alarms from "real" alarms, it is necessary to know the course of the heart rate and respiratory curve before and during the alarm situation. In order to achieve this additional memory storage capacity is necessary which is not provided in the current apparatus. An appropriate modification which should also consider transcutaneous p02 and pC02 determinations should be the objective of further research and development.

\section{Summary}

Cardiorespirography is a well-known method of continuous monitoring in neonatal intensive care. Apneic attacks, bradycardia and tachycardia are registered. In our experience we connected a cardiorespirography recorder to a microprocessor system. The processor consisted of a hardware part including a program (software) and a printer which provided printouts of alarm events.

As alarm situations, which cause an alarm printout, we defined:

1. apneic episodes (duration 10,20 or 30 seconds)

2. tachycardiac (beat-to-beat rate $>180 /$ minute)

3. V-shaped and U-shaped bradycardia (beat-to-beat heart rate $<80 / \mathrm{min}$ ) and combinations.

The reliability of the system of recognizing and classifying alarm situations was tested by comparing the alarm printouts with the simultaneously recorded cardiorespirograms.
Fifty eight 12 hour records of 41 patients were evaluated. Six hundred alarm situations were counted. The alarm printouts were found in concordance with the cardiograms in all tachycardia alarms. Nearly all bradycardia (V-shaped, U-shaped bradycardia, combination of bradycardia and apnea) were correctly classified. A preset apnea duration of 10 seconds resulted in many false positive alarm printouts. With 20 second apnea time only few false positive alarms were seen, but nine apneic attacks were not recognized.

Altogether $81.5 \%$ of alarm printouts were correct, $16.8 \%$ were false alarms, or V-shaped bradycardia were really U-bradycardia. Only $2 \%$ of all alarms were not recognized by the microprocessor system. We suggest to combine the microprocessor with a special alarm recorder, which is able to store beat-to-beat heart rate and respiration wave before alarm situations.

Keywords: Apneic episodes, cardiorespirography, heart rate changes, microprocessor. 


\section{Zusammenfassung}

\section{Mikroprozessorgestützte Langzeitcardiorespirographie} I. Herzfrequenzalterationen und Apnoeanfälle

Die Cardiorespirographie ist seit längerer Zeit als Überwachungsmethode für Früh- und Neugeborene bekannt. Apnoeanfälle, Bradycardien und Tachycardien werden an Hand von Schreiberaufzeichnungen erkannt und dokumentiert. Bei den vorgelegten Untersuchungen wurde ein Cardiorespirographieschreiber mit einer mikroprozessorgesteuerten Recheneinheit kombiniert. Letztere bestand aus einem Hard-ware-Teil, welcher in Halbleiterspeichern die Verarbeitungsalgorithmen in Form eines Programms (Soft-ware) enthielt und aus einem Metallpapierdrucker, der bei Alarmsituationen Ausdrucke lieferte.

Als Alarmsituationen, die derartige "Alarmausdrucke" veranlaßten, wurden definiert: 1. Apnoeanfälle von 10, 20 oder 30 sec Dauer; 2. Tachycardien (Herzfrequenz $>180 / \mathrm{min})$; 3. V-förmige und U-förmige Bradycardien (Herzfrequenz $<80 / \mathrm{min}$ ), sowie Kombinationen.

Die Zuverlässigkeit der Recheneinheit in der Erkennung und Einordnung von Alarmsituationen wurde durch Vergleich der "Alarmausdrucke" mit den simultan aufgezeichneten Cardiorespirographieschrieben ermittelt. Insge- samt wurden 58 zwölfstündige Aufzeichnungen von 41 Patienten ausgewertet. Es wurden 600 Alarmsituationen ausfindig gemacht. Bei allen Tachycardiealarmen stimmten Ausdruck des Rechners und Cardiorespirographieschrieb überein. Nahezu alle Bradycardien (V-förmige, U-förmige Bradycardie und die Kombination Bradycardie und Apnoeanfall) wurden richtig erkannt. Wenn die Apnoezeit mit $10 \mathrm{sec}$ vorgewählt wurde, ,übersah“ der Rechner zwar nie Apnoeanfälle, aber die Zahl der falsch positiven Alarmausdrucke war sehr hoch. Bei $20 \mathrm{sec}$ Apnoezeit wurden wesentlich weniger falsch positive Ausdrucke ermittelt. Allerdings fanden sich dabei auch neun nicht erkannte Apnoeanfälle. Insgesamt waren 81,5\% aller Alarmausdrucke richtig, in 16,8\% erfolgten Fehlalarme, oder V-Bradycardien waren in Wirklichkeit U-Bradycardien. Knapp $2 \%$ aller Alarme wurden vom Rechner nicht erkannt.

Eine Kombination des verwandten Mikrorechners mit einem Alarmschreiber, der in der Lage ist Herzfrequenz und Atemkurve vor und während einer Alarmsituation mit Hilfe einer Speichereinheit aufzuzeichnen, wird vorgeschlagen.

Schlüsselwörter: Apnoeanfälle, Cardiorespirographie, Herzfrequenzalterationen, Mikrorechner.

\section{Résumé}

Méthode de Cardiorespirographie à longue terme, basée sur les microprocesseurs

1. Changements en fréquence cardiaque et épisodes apnéiques. La cardiorespirographie est une méthode bien connue de monitoring contenu dans des soins intensifs néonatal. Des phases apnéiques, bradycardies et tachycardies sont enrégistrées. Dans notre expérience, nous avons connecté un enrégistreur cardiorespirographique à un microprocesseur. Le processeur était composé d'une partie hard-ware incluant un programme (soft-ware) et une imprimante, laquelle en cas d'alarme imprimait sur un papier métallique.

Nous définissons comme situation d'alarme, déclenchant le système d'impression,

1. des épisodes apnéiques (durée 10, 20 ou $30 \mathrm{sec}$ )

2. tachycardies (fréquence cardiaque) $>180 / \mathrm{min}$

3. bradycardies de forme $\mathrm{V}$ ou $\mathrm{U}$ (fréq.card. $<80 / \mathrm{min}$ ) ainsi que leurs combinaisons.

La fiabilité du système de reconnaissance et de classifications des situations d'alarme était testée en comparant les impressions d'alarmes simultanément avec l'enrégistrement cardiorespirographique.
Les 58 enrégistrements de 12 heures de 41 patients ont été évalués. 600 situations d'alarmes furent comptées. Dans toutes les alarmes tachycardiques les impressions d'alarmes étaient en concordance avec les cardiorespirogrammes. Presque toutes les bradycardies (bradycardie de forme $\mathrm{V}$ et $\mathrm{U}$, combinaison de bradycardie et apnée) étaient correctement classifiées. Pour un temps de latence apneique de 10 secondes il y avait beaucoup de faux positifs sur l'enrégistrement d'alarme.

Avec 20 secondes de temps de latence apneique, seulement peu de faux positifs furent enrégistrés, mais 9 attaques apnéīques ne furent pas reconnues.

Somme toute $81,5 \%$ des enrégistrements d'alarme étaient corrects, $16,8 \%$ étaient faux ou des bradycardies de forme $\mathrm{V}$ étaient en réalité de forme U. Seulement $2 \%$ de toutes les alarmes n'étaient pas reconnues par le système microprocesseur. Nous suggérons de combiner un microprocesseur avec un enrégistrement d'alarme lesquels sont capables de stocker la fréquence cardiaque et l'onde respiratoire avant des situations d'alarmes.

Mots-clés: Cardiorespirographie, changement de fréquence cardiaque, épisode apneique, microprocesseur.

Bibliography see part II. 